\title{
A ESTÉTICA DAS HERESIAS DE JOSÉ EMÍLIO-NELSON
}

\section{THE AESTHETICS OF HERESIES OF JOSÉ EMÍLIO-NELSON}

\section{Daniel de Oliveira Gomes* $U E P G$}

Resumo: O presente ensaio analisa a obra de José Emílio-Nelson, poeta contemporâneo do norte de Portugal, cuja mão escrevente é a do "grande masturbador das heresias". Estudamos o modo como este trabalha a figura habitual do Cristo católico em sua estética, sob a ética do sacrifício onde o profano e o sagrado se misturam.

Palavras-chave: José Emílio-Nelson. Poesia portuguesa. Heresia. Surrealismo.

Abstract: This essay analyzes the work of José Emilio-Nelson, contemporary poet from northern Portugal, the poet's hand is the hand that profanes. Here we study how the usual catholic image of Christ works in auctor aesthetics, particulary the ethic of sacrifice, in which the profane and the sacred are mixed.

Keywords: José Emilio-Nelson. Portuguese poetry. Heresy. Surrealism.

"E a tua benta Cruz de Deus vencido,/ Quis eu erguê-la em minhas mãos escravas! (...)” (José Régio)
* Doutor em Literatura pela Universidade Federal de Santa Catarina

\section{As teclas do sacrifício de J. E-N}

Seus poemas são como ritos de sacrifício: José Emílio-Nelson, autor do norte de Portugal (Espinho, na região metropolitana do Porto), prestes a completar seus 70 anos, cuja mão é a do grande masturbador das heresias: a mão poética que toca o órgão da palavra ritualizando orgasmos profanos. Mão que vem transportando uma pesada cruz poética por sua própria via crucis. No Brasil, Emílio-Nelson tem passado praticamente despercebido, desde Polifonia (de 1979) até Falsa Porta (de 2014), uma produção beira quase trinta obras, dentre as mais distintas: Extrema Paixão (1984); O Anjo Relicário (1999); A Alegria do Mal (2004); Bibliotheca Escatologica (2007); Coroa de Espinhos segundo (2010) e Pesa um boi na minha língua (2013). Como abancaria Maria Estela Guedes, recentemente:

Beleza tocada, o mais recente livro de José Emílio-Nelson, Obra poética, em subtítulo, reúne as obras que publicou entre 1979 e 2015. São quase 
740 páginas de prosa e verso muito difíceis de criticar, por diversa ordem de razões, a mais óbvia por se tratar de literatura fescenina e iconoclasta. Ela ataca alguns dos pilares da nossa cultura, como a moral sexual. Não é sequer fácil de citar, mas daremos o exemplo breve e mais laboratorial do que animal da página 381, centrado nuns fetos conservados em frasco num museu, coligido n"A festa do asno (apesar de o bestiário implicar mais os cães - incluídos os cães do Senhor, ou dominicanos - do que $O$ burro de ouro de Apuleio):

Na frascaria das prateleiras
altas, Na penumbra da sala,
Uns fetos em gosma floresciam pelo brilho da chapa em
latim que
os
legenda
va.

Um crucifixo, verdete.

E um dístico que nos alivia.

(Quem chora a morte a cão que renasce?)

Não devíamos considerar a originalidade um caráter exclusivo do autor que assim classificamos. José Emílio-Nelson é um dos poetas mais originais que conheço a escrever na nossa língua, apesar de se integrar numa linhagem que vem desde autores clássicos, passa pelas cantigas de escárnio, por Rabelais, Bocage, por Sade (e por Munch e Masoch entre outros, n`A palidez do pensamento, pp. 101-111), pelos frades escrevinhadores d`O Palito Métrico, etc., e chega ao Abjeccionismo, onde se encontra, ou onde eu lhe promovo encontro, com o também originalíssimo João César Monteiro. Esta lista pode ser alargada às centenas de nomes e até ao anonimato dos decoradores de catedrais, com as suas figurinhas obscenas a acompanharem nas gárgulas o escorrimento da chuva ou desenharem o portal para o divino. (GUEDES, 2017, on-line ${ }^{1}$ ).

Percebo que, muitas vezes, na poesia de José Emílio-Nelson, a figura habitual do Cristo católico parece ser o animal abatido, a oferenda preferida, vide que Cristo aparece, quase sempre, cadáver ou ainda jacente. Como se Emílio-Nelson fotografasse, em poesia, “Cristo-oferenda”. A obsessão é pelo corpo de Cristo, a paixão de Cristo, a ética do sacrifício, e jamais pelo mito de Cristo, sua moral, seu significado transgredido ou não. (A característica fotográfica, por mais que anamórfica, constitui um dado que a sua rara crítica vem constantemente apontando em sua obra). A palavra de Cristo, ou a palavra cristã (ou nietzscheanamente anticristã) nunca entrarão realmente em questão, como assunto de reflexão, como seria em uma poesia de teor mais dogmaticamente religiosa ou irreligiosa, ou uma prosa ferina que tentasse repolemizar a hermenêutica de Cristo - quais as narrativas de J. Saramago, Norman Mailer ou D. H. Lawrence, ou mesmo o filme Evangelho Segundo São Mateus de Pasolini. Porquanto o que desponta em Emílio-Nelson é, antes,

\footnotetext{
1 Ensaio originalmente publicado na revista Incomunidade (Março de 2017), em: http://www. incomunidade.com/ v54/art.php?art=71
} 
a anamorfose do Cristo Morto tomado na imagem-oferenda de um ato poético como rito de sacrifício. Ato poético este que vem para denunciar, dentre outros aspectos, nosso “corpo sem órgãos”, nossa submissão ao horror. O faz como se pela poesia obrasse, igualmente, uma mescla escritural/escultural, seguindo a atmosfera das esculturas de Gober - que são "símbolos de um corpo ausente” (CORTÉS, p. 206). Uma nova operação escritural/escultural miscigenada, por vezes, com a antiga atmosfera (da crucificação) de algum escultor barroco peninsular como Gregório Fernandez (vide Cristo de La Luz, obra dos primórdios do séc. XVII).

A mão poética com a qual o eu-lírico, em geral, apresenta em palavras seu Cristo Morto não o faz, ao modo irônico, antitético, um ente humanizado ou tornado símbolo marxista, símbolo de resistência cristã; ao contrário, é um Cristo dobrado em duplo estatuto: fragmentado (que representa, em seu horrendo espetáculo, a nossa orfandade do divino), mas também totalizado (sem nenhum traço socialista, uma imagem total do crucificado).

O Jesus social é o exemplo da metamorfose da fraqueza em força, ou, como diria Régis Debray: “o modelo dos órfãos em busca de mitos de identificação” (p. 333). Mas, em Emílio-Nelson, é a orfandade do corpo de Jesus o que interessa, a sua consternação, a carcaça abandonada de um Cristo que passa ao largo de qualquer imagem sociológica ou teológica. Cristo enumerável, satirizado, abandonado, imagem-de-cristo. Cristo-escultura (um logotype) que, assim, pode ser também “Cristos”, em reprodutibilidade, no plural, ou seja, coisas enumeráveis, comparáveis a um gomil de cebolas ou um disco já riscado, Cristo que pode ser um artefato abandonado, "traste”, como em fragmento de Opera Commedia:

Prendo à casa algum allegro, lixo

De antiquários, Cristos, funesto nas cores da sua chaga, espinhos de verdetes,

relógio, um gomil, cebolas, a poltrona entravada, santos com tochas, um

disco, Don Giovanni, já riscado, porcelana Cuja única beleza estará no logotype. Tudo Tralhas que conheceram outra trela E que são agora perfeitos, pesados sacos de areia de cenário. (EMÍLIO-NELSON, Bufão, 2004, s/p).

É o descarte do Crucificado, o morto-por-algo. [Seria forçoso imaginar que Emílio-Nelson talvez queira, por vezes, retratar (apresentar ou representar) a "impresentabilidade de Deus" (NANCY, La Mirada del Retrato data? p. 57)?] A ausência de Deus diante da presença do Crucificado, como se este fosse um objeto largado? Antes, a probabilidade infernal de qualquer rito de sacrifício. Uma encenação louvável, ferina, qual uma tela barroca, tomemos Caravaggio (e seu Jesus como “efebo andrógino e roliço”, diria Régis Debray). “Cálida a luz do anjo/ É dádiva./ Em Caravaggio o nu dá a Deus/ Um molde canhestro e/ De amargor.” Nesses momentos, Emílio-Nelson preocupa-se em 
mimetizar o tenebrismo, reforçar a luminosidade sombria desta poesia-tela em que ele (pro)põe o seu Cristo. Em outro poema, ele pergunta “E Deus”?²

\section{LA DEPOSIZIONE DALLA CROCE (MANTEGNA)}

Encerra a morte o cadáver de Cristo? (Agoniza e lavam-Lhe com lágrimas a chaga.) Sagrado Lenho. E Deus?

(EMÍLIO-NELSON, A cicatriz do Tempo, 1994, s/p)

O poema acima parte da tela renascentista do século XV, de Andrea Mantegna, tela esta que tematiza o fim da paixão de Cristo (a deposição do seu corpo da cruz). Em suma, o temos dado em imagem grotesca do corpo imolado, com a mão suja de sangue deixada presa no "rasgão do cravo".

Uma imagem mais cabal como abaixo, no poema que leva o título de outra tela de Mantegna, mas possivelmente faz remissão à tela de Rogier van der Weyden, onde todos os personagens jazem em lamentação por "lágrimas nodosas":

\section{CRISTO MORTO}

Lágrimas nodosas para o cadáver jacente. E a cabeça, coágulo seco, repousa penitente

Daqueles que tudo empestam de sofrimento. Cadáver ainda homem

Deixado

No rasgão do cravo.

(EMÍLIO-NELSON. A visão do antigo, 1995, s/p)

Figura 1: Rogier van der Weyden. Deposizione, Museu do Prado, Madrid. 1433.

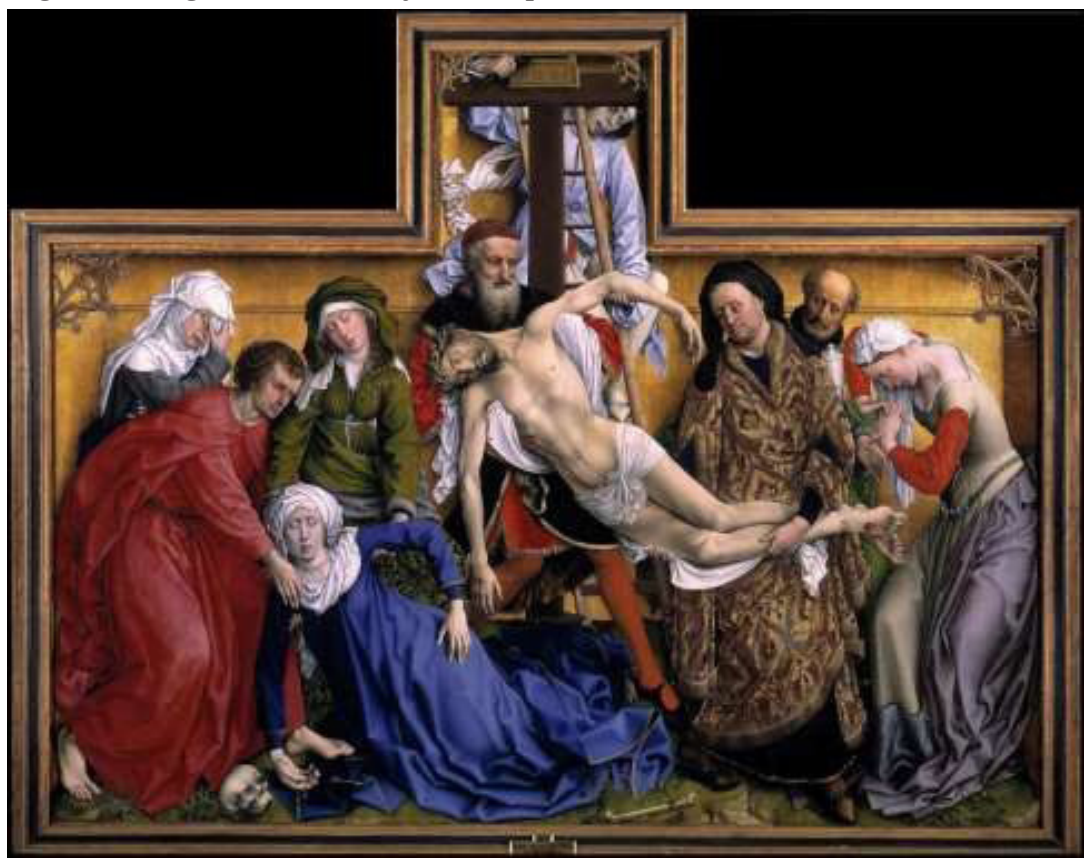

${ }^{2}$ Nesta pergunta por Deus, em EmílioNélson, aqui caberia muito bem lembrar de Deus como "rebaixado" na morte de Cristo, como põe Debray: “(...) A Paixão fascina o Ocidente. A ponto de esquecer (de tanto fixar os olhos no descarnado) que, sendo a trindade divina indivisível, foi o próprio Deus quem suou sangue e morreu no Crucificado. Ele se "rebaixou" no Filho a fim de elevar-nos até Ele, esvaziou-se Nele, por meio de uma transferênca de substância batizada de "kenose"e, do temo grego kénos "vazio". Resultado inaudito: Deus faleceu. Durante três dias ele deixou de existir. O nascimento de Cristo ocasionou pela primeira vez a morte de Deus. Ressucitou no domingo de Páscoa. Mas, para nós, o único redivivo é Jesus Cristo.” (DEBRAY, 2004, p. 320).

Fonte: Imagem disponível em: https://art4arte.wordpress.com/tag/mantegna-cristo-morto 
Tal como a pergunta dos versos de Jorge de Lima - "Senhor Jesus, o século está pobre./ Onde é que eu vou buscar poesia?” - J. E-N despe-se de todos os belos mantos para buscar ferramentas insanas no campo da pintura. O que usualmente parece fascinar o poeta é o enigma das telas, das chagas, a dádiva do imolado, converter-se assim em um poeta-andarilho caçando inspiração por inúmeros museus da Europa, acompanhando exposições de obras primas que retratem o crucificado como modelo estético "daqueles que tudo empestam de sofrimento”. Deste modo, pela mão de Emílio-Nelson vai o Cristo sujo, viscoso, plástico, obscuro (o belo tenebrista, portanto). Se em um museu encontrarmos um velho poeta solitário que optou em rabiscar seus versos frente a Cristo na Cruz, este é J E-N, blasfemando ao seu modo, imerso em sua santa loucura. Por ordem de várias dificuldades de sua incomum estilística, José Emílio-Nelson é um autor original que se nega à predação (qual poria Maria Estela Guedes). A notável disposição gráfica da capa de Beleza tocada evidencia isto muito bem:

$$
\begin{gathered}
\text { B } \\
\text { EL } \\
\text { EZ } \\
\text { ATO } \\
\text { CA } \\
\text { D } \\
\text { A }
\end{gathered}
$$

As primeiras letras tornam-se sílaba e esta transforma-se em palavra, Bel. Bel, antigo deus ainda resistente em topónimos como Belmonte, foi transformado em Demónio pelos padres, quando a cristianização soterrou as culturas primitivas. É Belzebu, o Senhor das Moscas, é ele quem toca a beleza, é a sua larva que faz apodrecer a maçã do Paraíso. Os sátiros abundam nesta lírica, a assegurar-lhe a valência satírica, ou mesmo satânica, como se lê logo na abertura do livro Extrema paixão, de 1984, com o poema intitulado "Satan", e como vemos logo em epígrafe, quando o autor descreve a Santa Língua, tocada e bífida, como a da serpente do Paraíso. (GUEDES, 2017, on-line). 
Figura 2: Capa da última obra de J E N, lançada em 2016, em Lisboa, pela Abysmo Ed. “A Beleza Tocada. Obra poética. 1979 - 2015.”

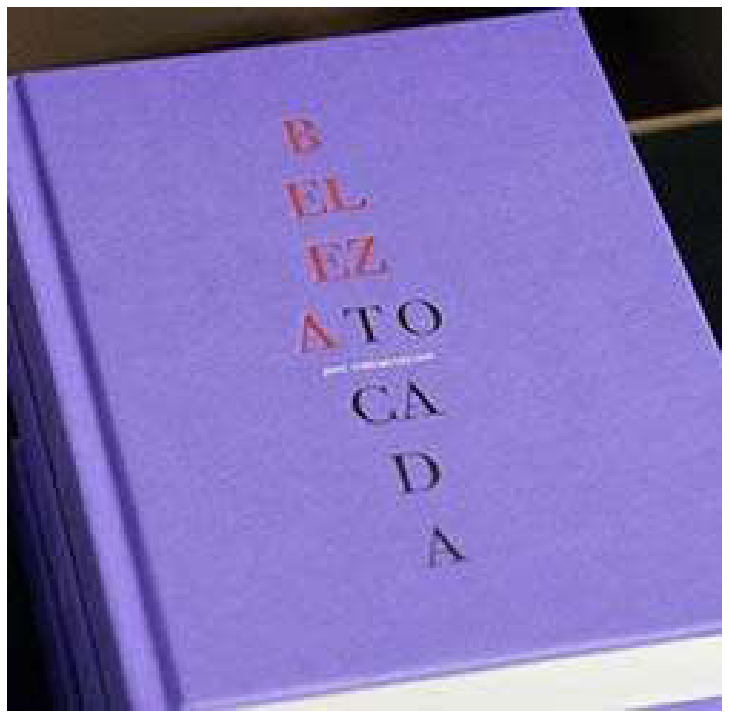

Fonte: Foto retirada do recente artigo de Maria Estela Guedes, na revista Triplov, disponível em: http://www.triplov.com/estela_guedes/2017/beleza_tocada.htm

Outros poemas trazem-no aos avatares de uma figuração secundária, tirando-o, Cristo, do protagonismo do assunto, mesmo assim, ali também estará o Senhor, porém fragmentado, como um elemento qualquer da poesia, próximo ao escatológico (“escato- ateologia”, descreverá o próprio poeta em 2008, no encontro “Correntes D’Escritas”) em todos os seus sentidos, excrementos, ranhos, viscosidades, metafísicas, alma, inocência, como nos últimos versos do poema abaixo:

Ela, a pequenina infância, andará ainda aí sentada com um velho nas nádegas e

o crucifixo saltando no pescoço, a negra mão do talismã buscando o brinquedo na vitrina

já contemplado.

Ela, a infâmia, bordando com dedal

botões de rosa em vez do cardo da minha lapela.

Ela deixada ao acaso

na borda do velho tanque de água que a rã tomba.

Ela permanece correndo pelo peão sonoro e pelo cão metálico como a alma

das mães a quem Cristo deu a mantilha para assoar o ranho da placenta.

(EMÍLIO-NELSON. O anjo relicário, 1999, s/p) 
Este poema, No fim a infância, que sugere a infância por aí sentada com algum velho, abre-se como uma autoreferência da memória do poeta, uma vez que reconfigura, por provável, uma tapeçaria medieval daquelas com que Emílo-Nelson teve contato em excursões escolares anuais, desde a sua infância, no "Museu Nacional del Prado": riquíssimo acervo de obras medievais, renascentistas e barrocas. E Emílio-Nelson guardará em sua memória-relicário esta profunda sensação inexprimível da testemunha infantil, angelical, ante aquelas telas de sacrifício. Se Nietzsche falava, em “Aurora”, do "perigo da inocência” (onde os inocentes sempre são as vítimas do cristianismo, que por sua vez faz da ignorância uma virtude, transmutando a inocência infantil em inocência cristã), Emílio-Nelson tenta então negar esta segunda inocência, por meio de uma imaginação envenenada pelo sonoro “cão metálico”. Talvez o poeta procure, sob a fórmula de confissão poética, com a "negra mão do talismã”, alcançar “o brinquedo na vitrina”, ou seja, compartilhar-nos seus segredos inapreensíveis, ambivalentes, mimetizar sua infantil e primordial inapreensibilidade: o peão do horror (o mesmo giro da acepção de compaixão feita por Nietzsche, em “O anticristo”. Pois para o filósofo alemão não haveria nenhuma vontade de poder, nenhuma bem-aventurança na noção de fraqueza do crucificado. E pela mão de J. E-N, redondamente nesta mesma esteira, a poesia ali está para desenhar a decadência no sublime e vice-versa). Quererá nos possibilitar, a nós leitores, o mesmo olhar da criança abismada, ao mesmo tempo exaltada, que terá sido ante o impactante contato com o acervo do Museu do Prado (para ele, a descoberta de que “o Tempo é pavor”):

A travessia pelas pinturas negras de Goya Calcadas por caminhos intrincados./ Nessa torrente recomeça o Mundo.

O Tempo é o pavor, desde sempre Um manto curto que resolve a Vida.

(EMÍLIO-NELSON. Como Falsa Porta, p. 432) 
Figura 3: Francisco de Goya. Saturno devorando a su hijo Museu do Prado. Madrid. (1819-1823)

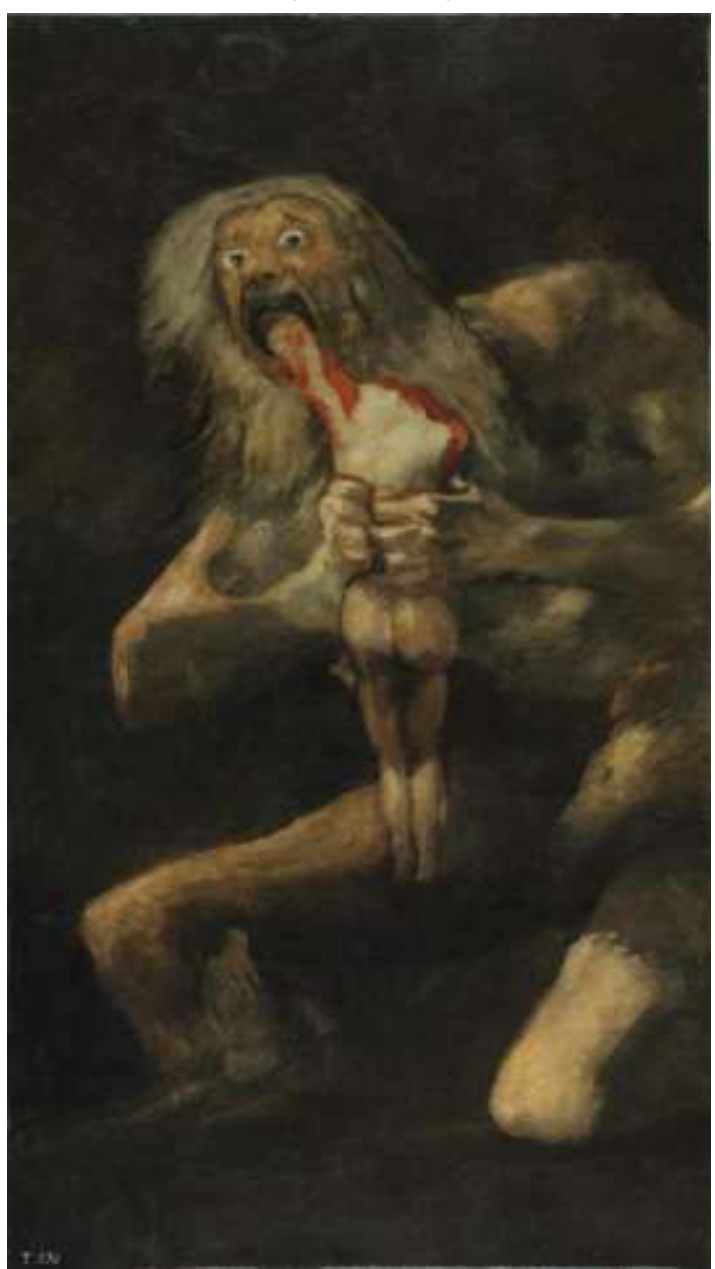

Fonte: Disponível em: https://br.pinterest.com/pin/412149803379970327/

\section{A heresia clássica, a mão obscura}

Em outro de seus poemas, A obscura pergunta - publicado na ontologia de 2010-2012 irreverentemente intitulada Pesa um boi na minha língua - temos a imagem da mão que “aparece e desaparece” dentro de nós (capazes de poesia):

Que mão desaparece e aparece por dentro de nós?

É mão ainda a que desce sobre os versos? Mão agónica? Qual mão? A que se mortifica muda e confusa e nos consome Ou a que evola Deus?

(EMÍLIO-NELSON. Pesa um boi na minha língua, 2012, s/p) 
É a “obscura pergunta” que aqui estou a explorar, pensando na poética de José Emílio-Nelson. Eis a pergunta, quem sabe, ecoando velada e viciosamente em todos os seus poemas: a pergunta sobre esta mão sinistra que “evola Deus”, ferida de poesia, agônica, desagregada do corpo, do corpus. É como se lêssemos poesias incompletas, maléficas (mas sem negativismo), escritas por uma mão mutilada, sádica e andrógena, por exemplo, uma das mãos decepadas de uma instalação hiper-realista de Robert Gober ${ }^{6}$ (ou a mão assada de Van Gogh).

Figuras 4: Esculturas e instalações de Robert Gober entre os anos 1990 e 2000. Instalações exibidas em: Schaulager, Basel 2007; Matthew Marks Gallery, 2005;
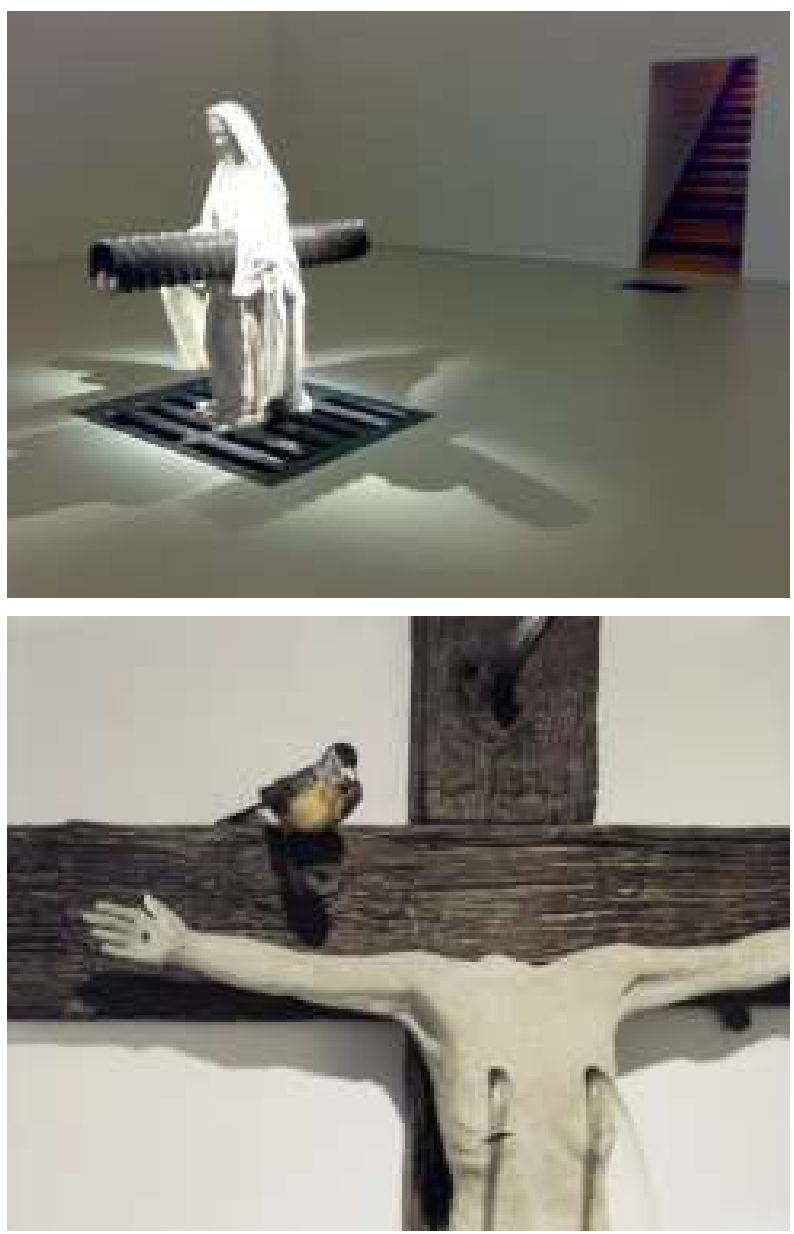

${ }^{1} 6$ Robert Gober é um artista plástico muito irreverente, conhecido por suas instalações escatológicas, dentre elas, braços e pernas decepados e mutilados que assumem um tom surreal e instigam o expectador a pensar tanto a função do museu quanto a função do corpo, da arte, do belo, etc. Em especial a partir dos anos 90, esta irreverência se amplia, quando a obra de Gober deu uma guinada maior ao dramático e ao drástico (apresentando estas mutilações corporais). Como dirá Miguel Cortés: “(...) Gober es uno de los artistas americanos contemporáneos que, sin hacer de su obra un panfleto propagandístico, está tratando de construir un discurso artístico e social que dé la oportunidad al espectador de encontrar otras visiones que no sean necessariamente, heterosexistas. Su obra, y la de algunos otros, rompe con la opresión que significa marginación de identidades sexuales." (CORTÉS, 1996, p. 213). 


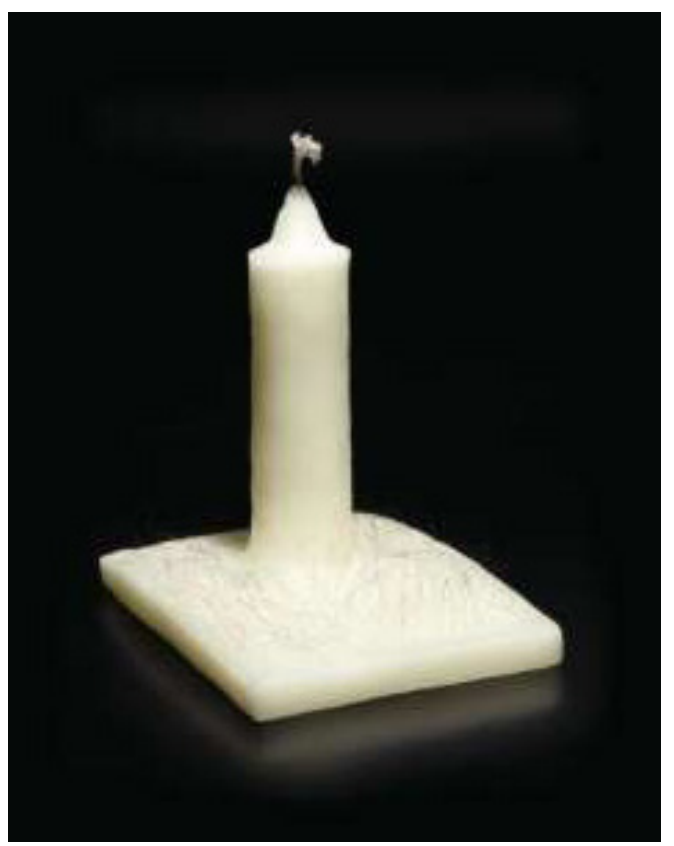

Fonte: imagens disponíveis em: http://www.matthewmarks.com/new-york/artists/ robert-gober/selected-works/

Proponho, em primeiro lugar, que suas poesias fazem reverberar uma estranha voz sagrada, repleta de uma potente “alegria do mal” e que, por sua irreverência e soberania cruel, exigirá um dado "acatamento" do profano, ou seja, afastará um leitor desavisado ou aquele que Bataille chamaria de "um homem angustiado" - leitor que se revolta com as propostas de Sade (Bataille, O Erotismo, p. 282). Observe-se o poema A mão Embalsamada:

A mão embalsamada de um poeta da ‘interrogação’ Ganhou ferrugem doirada

De tanto bater no santíssimo Verbo de Deus.

Cada dedo rogou por um anel e, fantasma anelado, Peregrinou com versos em estrofes enclausurado.

Dá-lhe, meu Deus, amado, um teclado para que suje a mão a escrever Sem, em troca, esperar a Glória.

E faz, meu Deus, que limpe o sebo dos olhos

E veja que não há lugar para o poeta à Submissão dado. (EMÍLIO-NELSON, Amor Repugnante, p. 456)

Uma impressão embrionária, em um elementar contato com a poética de Emílio- Nelson, denota uma relação estilística com a heresia clássica, na atmosfera antiga de alguma coisa que seria considerada, por volta do século XVII, no mínimo bruxólica. A imagem da “mão embalsamada” assemelha-se, para mim, também à imagem blanchotiana da preensão persecutória, a imagem 
da mão que segura o lápis do escritor como mão que se sabe incessante, mas também putrefacta, mão-cadáver (escritura como gesto interminável, inacabável, onde reina a indecisão do recomeço, diria Blanchot), mão que se preserva na embalsamação da escritura. No caso deste poeta, batendo espiraladamente “no santíssimo Verbo de Deus”. Mão obscura, intermitente, que volta a profanar.

Tomássemos a poesia de um poeta do início do séc. XX que sustentasse um vocabulário requintadamente português, penso em um poeta português por excelência, com bastante preciosismo em sua transgressão satírica, refiro-me a Antônio Patrício (1878-1930), veríamos já o paradoxo do fascínio pelo drama e sofrimento físico, ao mesmo tempo em que uma dificuldade em lidar com o trágico dá vez a um tom lírico, lacrimejante. Como na poesia As mãos Cortadas (poesia oriunda de 1915 quando Patrício vira uma criança a quem soldados cortaram as mãos). "Não tem mãos: foram cortadas/ (rouxeiam os horizontes)/ por facas ou por espadas...? (...) A criança tira os braços,/ os seus bracinhos sem mãos,/ dentre as roupas, muitos lassos...” (PATRÍCIO, Antônio, 1915). Outra poesia conhecida deste velho poeta, Antônio Patrício, é “Judas”, poema blasfemo em que o trágico novamente aparece, trabalhando o sofrimento de Judas de modo lusitano, ou seja, desculpabilizando-o pelo drama de Jesus. O texto é uma sátira pegando ao pé da letra imagens bíblicas. O incólume amor pelo sofrimento da poesia lusitana que também nos faz imaginar que Emílio-Nelson também bebe dessas águas, e muitas outras.

Estou tentando ponderar as particularidades de sua heresia poética escrita por uma mão agônica e enferma, simultaneamente a mão cavalheira, cavaleira, distinta, a cunhar nobres mosaicos heréticos - e não tanto o peso de seu acautelado ateísmo.

Não reivindiquemos o ateísmo para esta obra, pois toda grande obra é sagrada. Todo o herege sacralizou-se, porque é possuído pela fé. Somente uma fé inabalável, incontida, que se revela como vontade de viver pode gerar uma poética tão forte e tão exigente. Não seria correto dizer que esta poesia é um escárnio à fé. Antes pelo contrário, há uma reivindicação ou uma exigência para que ela seja devolvida ao homem; que ela o conduza para a totalidade que desde sempre ele persegue. Páginas de Hagiógrafo apresenta-se como uma exaltação, como um canto sagrado, pois esta é uma das maneiras de se fazer ouvir. E a contemplação garante a existência de uma obra de arte. Por outro lado, atentemos para o novo movimento ou para a nova contorção do Ocidente, marcada sobretudo pelo Seminário de Capri, onde Derrida afirmou que a fé tem a ver com o cerne mesmo da razão. E acrescentando, leiamos atentamente Nietzsche. Em Páginas de Hagiógrafo novas passadas do crítico e novo convite: uma força centrípeta suga-nos para o nosso próprio núcleo. Evidentemente que o chamamento nos empurra para olhar com olhos de bem se ver a religião católica. Não poderia ser outra, pois foi ela que se impôs e se estendeu e fez calar todos 
os que a questionaram ou não a aceitaram. Ela expulsou os últimos Deuses, que mesmo assim, sabendo o que viria, partiram às gargalhadas. E nos levaram o riso. Contudo, deixaram uma feliz herança: provaram que o humano não se pode confundir com o divino. Em boa hora nos chega A alegria do mal. (TEIXEIRA, 2014,on-line)

Figura 5: El Greco. El caballero de la mano en el pecho. 1580.

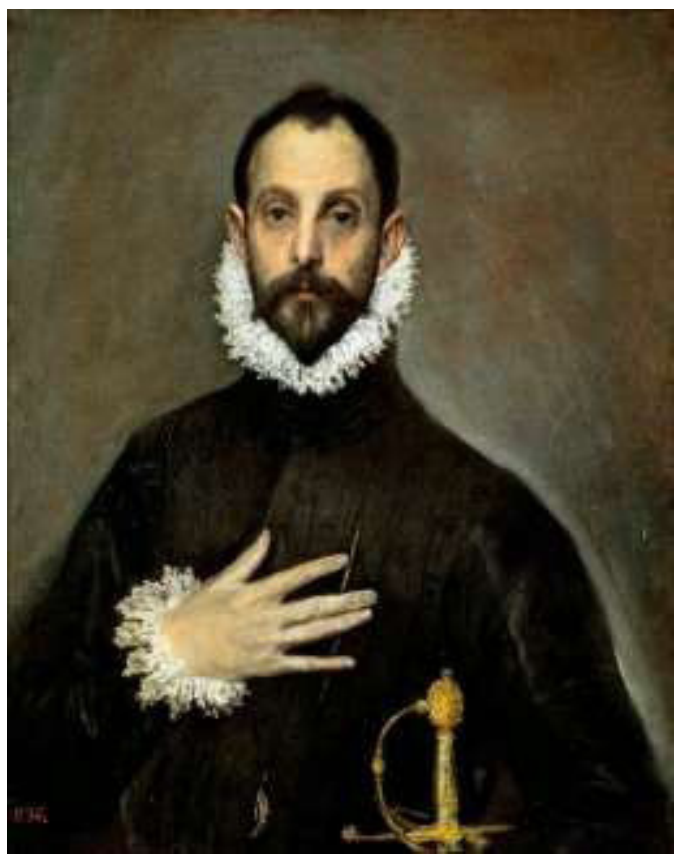

Fonte: Imagem disponível em: https://www.museodelprado.es/coleccion/obra-de-arte/el-caballero-de-la-mano- en-el-pecho

Podemos dizer que as imagens penetrantes de Emílio-Nelson põem-se sob um frenesi surreal e voluptuoso, criando planos e planos submersos, sempre e sempre numa espécie de aberração herética (porque como diz Teixeira, sua obra traz uma fé inabalável). Não se trata, portanto, apenas de uma nova modalidade de expor o ateísmo, buscando-se na poesia da pós-modernidade, ou de sustentar uma profanação do sagrado, de fragmentação do todo, mas sim de voltar a uma instância bataillana, penso, onde o profano e o sagrado realmente se mesclam. A nobreza e o deslustro, o sublime e o horror. Podemos, claro, o aproximar das figurações de Sade analisado por Bataille. Em um ensaio, Pedro Sena-Lino proporá que a tônica da poesia de Emílio-Nelson dá-se, justamente, em uma das formas de erotismo que Bataille propunha em seu $O$ Erotismo.

E como consequência desta mão que escreve - a de J. E-N - não temos nem a parte e nem o todo, não temos a totalidade sacral e igualmente não temos a fragmentação espiritual da ordem do ato profano. E nisso, também, 
é pontuada em seu estilo uma possível afinidade com o clássico, as tensões vocabulares e o experimentalismo hiberbólico, por exemplo. Paralelismos com as artes picturais, a sensualidade, o conceptismo, também estão bem presentes. Diríamos, igualmente, de uma relação atemporal, a busca de renovação de uma poesia mais antiga, pois ao mesmo tempo barroca e pós-moderna, tal como caracterizada, também, por Pedro Sena-Lino.

Fernando Castro Branco, ao falar de "Sonetos Glaucos", a primeira parte de Coroade Espinhos - Segundo, por sua vez, apontará que:

(...) desde logo a classicidade da forma imbrica-se indissoluvelmente com as temáticas, a arquitectura retórica e a linguagem, todas estas vertentes de cariz fundamentalmente neo-barroco, dando corpo a uma poética de índole pós-moderna que se faz eco, em Sonetos Glaucos, de figuras relevantes da literatura portuguesa como Vieira, Gil Vicente, Abade de Jazente, Cavaleiro de Oliveira, Gomes Leal, Tolentino, Bocage, entre outros, a que acresce, em lugar de destaque, Francisco de Quevedo, referência de sempre do autor. Daqui resulta um hipertexto cuja marca mais nítida é o satírico e o derisório. (CASTRO BRANCO, 2010, p. 2).

Muitas relações unânimes encontraremos entre Emílio-Nelson e velhos ou novos poetas hereges, a mão obscura que tece relação com "o obsceno, o agressivo, o blasfemo, o cínico, o de contra-senso” (tal como o professor Leodegário Azevedo Filho nomeava a Bocage, por exemplo) ou a relação com o experimentalismo atual capaz “(...) de lembrar um pouco o seu contemporâneo Alberto Pimenta, que também é um génio da aliança entre a erudição e a modernidade.” (GUEDES, 2014, on-line).

\section{El Grand Masturbador}

Acaso apanhássemos um poeta não tanto herético, mas igualmente satírico, como Gregório de Matos, pela senda das articulações entre cristianismo e as dimensões sensorialistas (poeta que esvai pela vereda das obscuridades, traz o gosto pelo sinistro e sublime) não estaríamos muito equivocados, em certa medida, em lembrar de traços temáticos da poética de Emílio-Nelson. A grande característica que vincularia ambos, neste caso, seria a exaltação e o elo entre a totalidade do divino e a parte humana, o elemento humano (como fragmentação). Vejamos neste soneto de Gregório de Matos como o eu-lírico tematiza o achado do pequeno bracinho de Cristo fragmentado (este braço quebrado por infiéis da imagem de Nossa Senhora das Maravilhas, adorada na Sé da Bahia).

O todo sem a parte não é o todo A parte sem o todo não é a parte

Mas se a parte faz o todo, sendo parte, Não se diga que é parte sendo todo 
Em todo Sacramento está Deus todo, E todo assiste inteiro a qualquer parte, E feito em partes todo em toda parte, Em qualquer parte sempre fica o todo.

O braço de Jesus não seja parte, Pois que feito Jesus em partes todo, Assiste cada parte em sua parte.

Não se sabendo parte deste todo,

Um braço, que lhe acharam, sendo parte, Não disse as partes todas deste todo.

Todo este soneto de Gregório de Matos está estabelecido no jogo opositivo entre parte e todo, mostrando não apenas que o corpo de Cristo permanece presente em qualquer parte da hóstia, como, também acaba por revelar aí um Cristo fragmentado ao menos como imagem. O tema não deixa de trazer à cena uma sodomização da figura de Cristo. Pensando em Emílio-Nelson, Cristo é igualmente e sempre estilhaçado, porém de modo herético - diríamos herético-erótico - e assim sendo blasfemo, por mais que retoricamente não se queira assumir exatamente blasfemo. A autosodomização surreal parece ser uma das características do poeta ao trazer em seus poemas a imagem de Cristo. Veja-se que, na estrofe abaixo, o braço de Cristo, a mão de Cristo, também aparece fragmentado, porém, masturbando o eu-lírico.

\section{EL GRAND MASTURBADOR (DALÍ) \\ [El Grand Masturbador que Dalí continua a pintar com El Greco, bizzarie, é um dejecto de Deus.] Cristo masturba-me, a bem dizer, o Seu olhar pesaroso é a minha cruz. Não há blas- fémia, é mesmo assim (ainda a penugem não carregava o rosto pueril da infância). Como estou céptico neste juízo da inocên- cia. Não há blasfémia, aceito passivamente a Sua paternidade. (A miséria das palavras não redime atribulações.) (EMÍLIO- NELSON. Sodoma sacrílica e poesia vária, 1991, s/p)}

Obviamente se vamos à tela El Grand Masturbador de Salvador Dali, não reconheceremos nenhuma imagem, mesmo em parte, da mão de Cristo, ou exatamente daquilo que Emílio-Nelson descreve. Logo, não se trata de uma descrição poética de um quadro surreal e sim um esforço de (des)dobramento “a partir” de Dali. É a “energia erótica primacial”, bem como as várias “enumerações multidirecionais”, como dirá Sena-Lino, que movem o estilo neobarroco, ou surreal, do poeta. A “bizzarie”, como diz o próprio poema, reside desde a caça inspirativa do artista. A mão que vai-e-vem ordenhando, em deleite, a impotência da representação: o falos do irrepresentável. 
Figura 6: Salvador Dali- "El grand Masturbador”. 1929. ${ }^{9}$

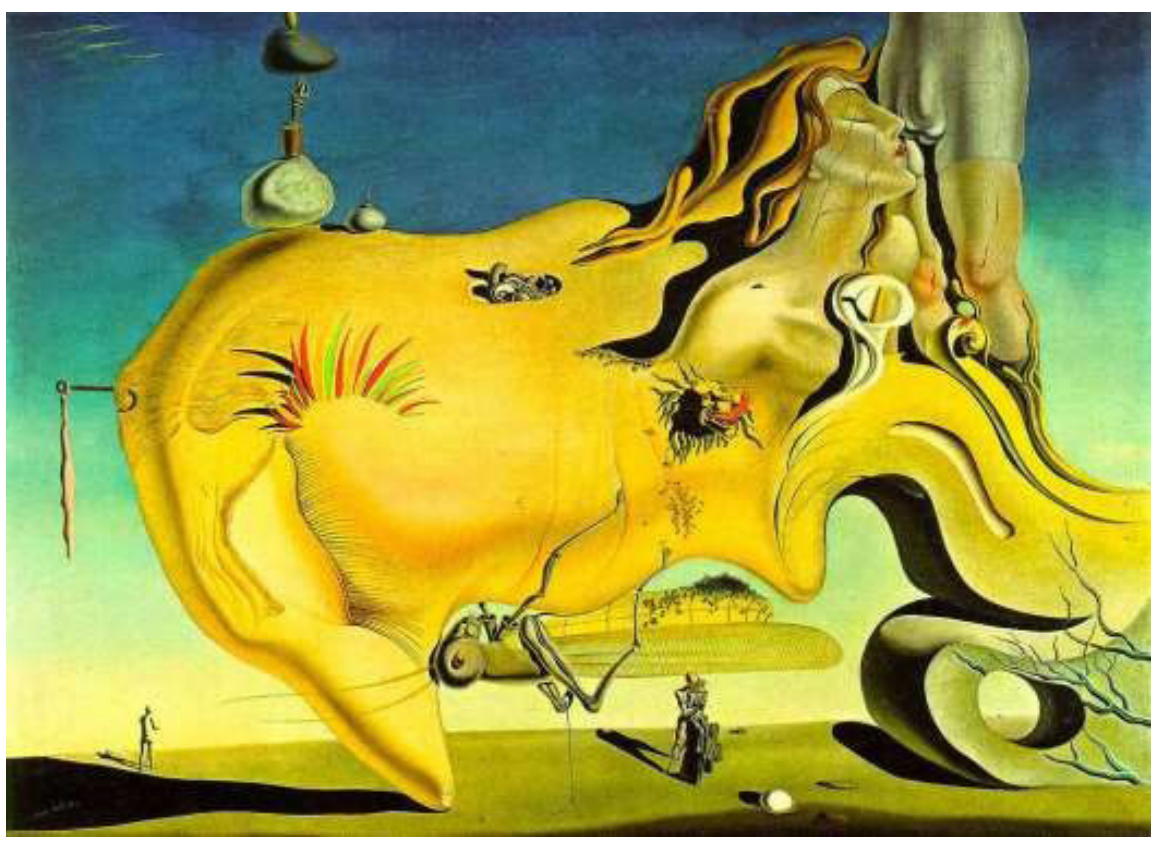

Fonte: Imagem disponível em: http://www.museoreinasofia.es/coleccion/obra/ visage-du-grand-masturbateur- rostro-gran-masturbador

É a sua própria mão-protésica-poiética, ao escrever suas composições, que traz em si uma tradição ancorada no aprisionamento metafísico do ocidente cristão e que busca, assim, em um desespero orgástico, punir-se eroticamente. E, busca, ao mesmo tempo, esquivar-se de algum modo desta tradição. (A cabeça de Dali está quebrada como uma iconoclastia, uma blasfêmia). O poeta nos revela que dentro da inocência de todo fazer poético está cooperando os movimentos da mão mutilada de Cristo crucificado, “el grand masturbador”. Ou, como quererá Sá Couto:

A mão de uma poesia que liberta objectos e seres da aparência comum, que é a artífice da denúncia da desventura terrena, e que enxertando-se de vozes evoca a procura da condição humana, só pode imprimir o Deus humílimo que se liberta da sua condição inumana para habitar o corpo desgraçado do Cristo agonizante da crucificação. (SÁ COUTO, 2014, on-line).

“Cristo, «dejecto de Deus», é aclimatado às ambiências sodomíticas em «El Grand Masturbador», pleno de reverberações dalinianas” (CARLOS, 2014, on-line). Uma tela onde Emílio-Nelson aparentemente vê Cristo como êxtase erótico na figura que salta como parte de uma cabeça também fragmentada. Analisando a tela, a figura tem suave alusão erótica posto acostar-se de um sacro escrotal. Este “falos" é apenas parte de um corpo também fragmentado pela tela, visível apenas da cintura para baixo. 
No entanto, a figura que erotiza e que Emílio-Nelson vê como Cristo que o masturba, possivelmente, é “Gala Eluard”, a musa inspiradora de Dali que aparece em tantas de suas telas surreais. Isto demonstra que, como sempre, em Emílio-Nelson o que atua é uma operação de dobra desde a tela, onde nenhuma hermenêutica absolutista será segura, afinal a parte e o todo, a vida e a morte, o erotismo e o sacrifício, o belo e o horror, angelismo e satanismo, possuem uma conexão sublime na visualização soturna de imagens blasfemas. Sua busca, dizem talvez sob um teor mais estóico, seria a da busca da ética onde se pudesse não apenas praguejar contra a sociedade ocidental judaico-cristã, mas sim, como supõe Castro Branco, buscar uma revelação ético-poética, com “heterodoxa originalidade” do próprio humano.

A posição de Emílio-Nelson enquanto esteta e poeta assenta fundamentalmente, embora o possa não parecer, numa plataforma ética de raiz estóica, que pairando sobre os básicos e comuns conceitos de ordem moral, comportamental e social, vai abrindo pelas veredas obscuras da ontogénese humana os indícios e sinais que lhe permitam mapear essa conjunção indiscernível de corpo e alma que identificam o humano. Qual "mão celibatária” que recusa nupciais compromissos com qualquer forma de conjuge que não seja a da inteireza da criação poética. (CASTRO BRANCO, 2010, p. 4).

Por fim, lembremos do poema Mão suja de Drummond que dizia: “Minha mão está suja. /Preciso cortá-la/ não adianta lavar./ A água está podre./ Nem ensaboar./O sabão é ruim./A mão está suja,/suja há muitos anos (...)”. Bem diferentemente desta manifestação gauche de Drummond, que com um traço asséptico ainda humanista- cristão nota a moderna mão suja (“ânsia de purificação”, dirá Antônio Cândido), mão responsável "há muitos anos” pela morte da beleza, do eternal, do bom-e-belo (e o eu- lírico em ato metapoético de Drummond tenta lavá-la, cortá-la, jamais logrando êxito).

Emílio-Nelson, por sua vez estóico - sem nenhum problema ético ou de culpa criativa - acata há décadas em sua poesia a mão suja e fragmentada, sublime mão poética, como figuração feia e bela ao mesmo tempo, conspurcada e limpa. Mão imperfeita que escava a imperfeição. Mão dantesca, entre o inferno e a divina comédia.

José Emílio-Nelson liberta a poesia dos compromissos morais e do estético asséptico para escavar a imperfeição, o inferno humano e a divina comédia da vida, dando-nos a ideia de que os bons sentimentos inviabilizam a inquietação imprescindível ao acto de criar. (SÁ COUTO, 2014, on-line).

Pois a sua mão sempre foi mutilada, mão de um bruxo de magia negra, “mão celibatária” (como diz Castro Branco), e é assim que se raia a alegria do mal em seu estilo. Divertimento debilitante de profanação inscrita pela mão sombria. Como apontará Luís Adriano Carlos, a beleza morrendo às mãos inclementes do tempo é algo que, de fato, fascina a Emílo-Nelson: 
Fascina-o a morte minuciosa da beleza às mãos inclementes do tempo. Por exemplo, na série «De tal Modo Olhámos», de O Anjo Relicário:

"A rosa de / Ronsard, / Retiro-a do soneto. / Murcho-a nas mãos». Ou na série «A Pompa da Morte», de Claro-Escuro ou a Nefasta Aurora:

«Rosa intocável / De orvalho / E pus. / Sangrando. / No suporte desabrochado / A mão é a rosa que uiva. / Entontece impiedosa / Em decomposição». (CARLOS, 2014, on-line)

Figura 7: Enquadramento fotográfico do ensaio “Irredentos” (2000) do fotógrafo Christian Cravo.

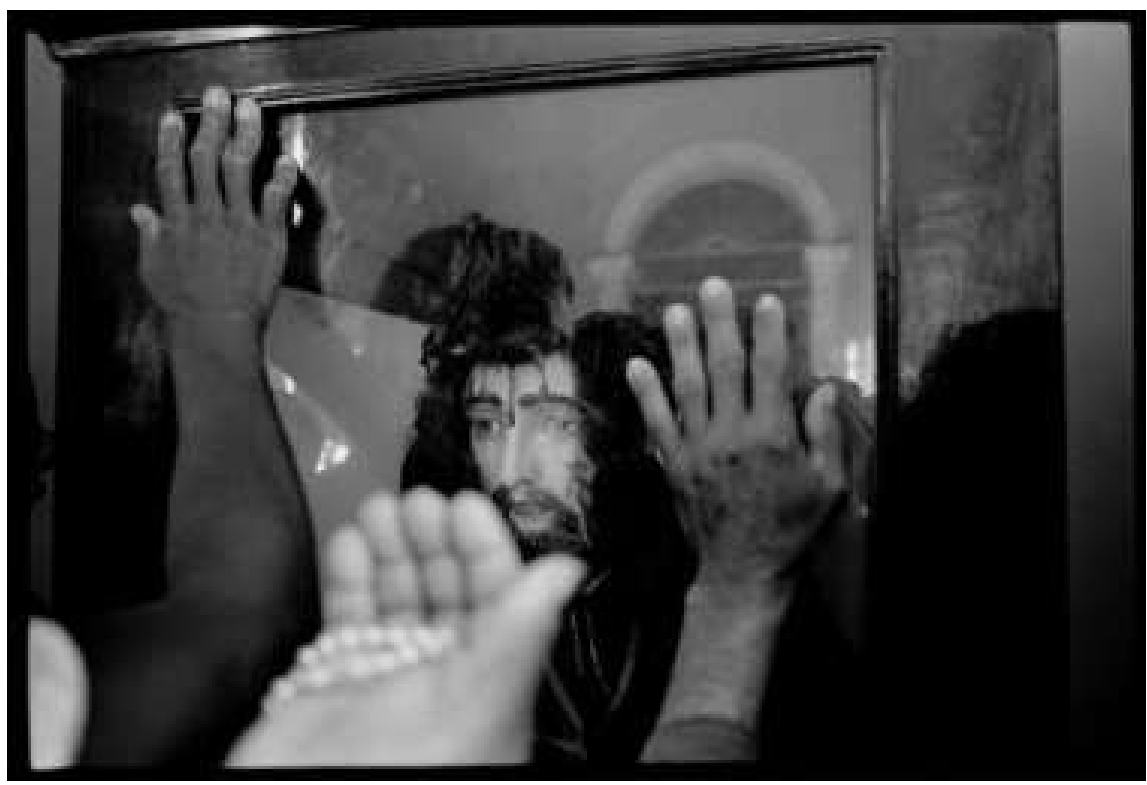

Fonte: Imagem disponível em: http://www.christiancravo.com/ensaio_fotos. aspx?id=24

\section{Referências}

ARTAUD, Antonin. Van Gogh o suicidado da sociedade. Trad. Aníbal Fernandes, Lisboa: MM, 1987.

Oeuvres Complètes. Paris, Gallimard, 1976.

BATAILLE, Georges. A parte maldita. Rio de Janeiro: Imago, 1975.

O Erotismo. Tradução de Cláudia Fares. SP: ARX, 2004.

BLANCHOT, Maurice. O Espaço Literário. Rio de Janeiro: Rocco, 1987;

. Une Voix Venue d’Ailleurs. Paris: Gallimard, 2002.

CARLOS, Luís Adriano, Introdução. Fisiologia do Gosto Literário. In: EMÍLIO- CASTRO BRANCO, Fernando de. "Para além do belo e do 
feio”. In: Teia Literária: Revista de Estudos Culturais, n. 4. Jundiaí: In House, 2010.

CORTÉS, José Miguel G. El Cuerpo Mutilado (La angustia de Muerte en el Arte). Barcelona: Graphic-3, 1996.

DEBRAY, Régis. Deus, um itinerário. Material para a história do Eterno ocidente. Trad. Jônatas Batista Neto, São Paulo: Companhia das Letras, 2004.

EMÍliO-NELSON, José. Mísero Canto. Obra Poética, 1979-2014.

Entrevista de José Emílio-Nelson em “Os Livros Ardem Mal”. Disponível em: http://olamtagv.wordpress.com/2008/12/05/inqueritoolam- jose-emilio-nelson/ Acesso em: 27 nov. 2014.

2016.

Beleza Tocada. Obra Poética 1979-2015. Lisboa: Abysmo Ed,

GUEDES, Maria Estela. Beleza Tocada em José Emílio Nelson. Disponível em: http:/www.triplov.com/estela_guedes/2017/beleza_tocada.htm

MATOS, Gregório. Poemas de Gregório de Matos. Org. Letícia Malard. Belo Horizonte: Autêntica, 1998. NIETZSCHE, Friedrich. Aurora/El Anticristo. (Biblioteca comemorativa Nietzsche). Madrid: Libsa, 2000.

SÁ COUTO, Teresa. Poesia de José Emílio-Nelson. Disponível em: http:/comlivros-teresa.blogspot.com.br/2013/09/poesia-de-jose-emilionelson.html. Acesso em: 13 dez. 2014.

SENA-LINO. Pedro. José-Emilio Nelson - Bibliotheca escatológica. In: Colóquio Letras, Secção Recensões Críticas, Lisboa: Fundação Calouste Gulbenkian, 18.05.2008. Disponível em: http:/coloquio.gulbenkian.pt/ bib/sirius.exe/news?i=5. Acesso em: 29 nov. 2014.

SLOTERDIJK, Peter. O quinto Evangelho de Nietzsche. Rio de Janeiro: Tempo Brasileiro, 2004.

TEIXEIRA, Neiza. Uma paragem obrigatória em “Polifonia”. Disponível em: http://antroposmoderno.com/antro-articulo.php?id_ articulo=967. Acesso em: 28 nov. 2014.

Recebido em agosto/2018.

Aceito em novembro/2018. 